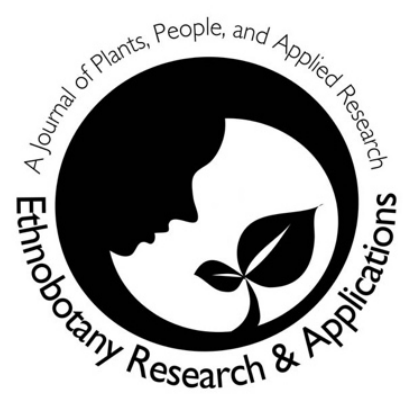

\title{
Medicinal uses of plants by traditional birth attendants to facilitate childbirth among Djimini women in Dabakala (Center-North of Côte d'Ivoire)
}

Silvère Romuald Koman, Wokapeu Blaise Kpan, Konan Yao and Djakalia Ouattara

\section{Research}

\begin{abstract}
Background: Today, due to the still high rates of maternal death and incessant caesareans, the high cost of pharmaceutical drugs, parturients are turning to traditional midwives to facilitate childbirth. The purpose of this study is to identify and document the medicinal plants traditionally used for their oxytocic effect by the traditional midwives in the department of Dabakala.
\end{abstract}

Methods: an ethnobotanical survey was conducted with 71 traditional midwives from the department of Dabakala. The data were analyzed with Epidata and SPSS 20.0 software. The Chi-square test was used to compare the percentages of the parts used, the method of preparation and the method of administration. To better interpret the cultural medicinal value of plants, several quantitative ethnobotanical indices have been used such as the Consensus for the Part of the Plant (CPP), the Contribution of each plant in the constitution of recipes (Cpr), the consensual value of types of use (Cs) the Frequency of recipes (Fr) and Relative frequency of citation (FRC).

Results: The results of this survey indicated that 48 species in 41 genera and 28 families are used by midwives for their oxytocic effect. The most represented family is the Fabaceae. Among the species cited, Portulaca oleracea, Alternanthera pungens, Ocimum americanum, Uvaria tortilis,
Blighia sapida are the plants most used for their oxytocic effect in the department of Dabakala.

Conclusion: These results constitute a database for subsequent studies aimed at assessing the biological and chemical composition of these plants.

Keywords: medicinal plants, traditional midwives, childbirth, Côte d'Ivoire

\section{Correspondence}

Silvère Romuald Koman ${ }^{1}$, Wokapeu Blaise $\mathrm{Kpan}^{1,2,3}$, Konan $\mathrm{YaO}^{2,3,4}$ and Djakalia Ouattara ${ }^{1,2}$

${ }^{1}$ Laboratory of Natural Environments and Biodiversity Conservation, Botanical Research and Training Unit, Félix Houphouët-Boigny University, 22 BP 582 Abidjan 22

${ }^{2}$ National Floristic Center (CNF), Abidjan, 01 BP 1303 Abidjan 03 (Côte d'Ivoire)

${ }^{3}$ Swiss Center for Scientific Research in Côte d'Ivoire (CSRS-CI), 01 BP 1303 Abidjan 03 (Côte d'Ivoire)

${ }^{4}$ Aké-Assi Botanical Institute of Andokoi, BP 582 Abidjan 22 Abidjan 01, Côte d'Ivoire

*Corresponding Author: kpan.blaise@ufhb.edu.ci

Ethnobotany Research \& Applications

21:23 (2021) 


\section{Background}

Childbirth is the set of physiological and mechanical phenomena ensuring the expulsion of the fetus and appendages from the genital tract (N'guessan et al., 2010). It is the most important act that occurs in a woman's life. Unfortunately, around 287,000 women die of pregnancy and childbirth worldwide each year (WHO, 2019).

Most of these deaths are in Africa where one in 21 women die during childbirth (N'guessan et al., 2009).

Today because of the still high rates of maternal deaths and the incessant cesarean sections and the inaccessibility of pharmaceutical drugs due to their high cost, traditional medicine appears to be the most appropriate alternative to face these difficulties. Indeed, for rural communities in developing countries, the use of plant species as remedies for the treatment of all ailments or diseases, provides them with an alternative for better health establishment with fewer side effects. Also, in recent years, it has occupied a prominent place in the medical practices of pregnant women in Africa (Yoro et al., 2017). The use of herbs during pregnancy is a common practice in Africa. In Côte d'Ivoire, despite the medical prescriptions issued during modern antenatal consultations, most pregnant women resort to traditional medicine to ensure the development of the fetus and to facilitate childbirth (Djah \& Danho, 2011).

According to a report by the Ivorian Association for Family Welfare, in rural areas, $70 \%$ of women give birth alone, at home or they are assisted by a family member or a traditional birth attendant (matron) (AIBEF, 2014). In these Ivorian societies, these traditional birth attendants administer medicinal preparations often made from herbal drugs which are sometimes associated with animal organs and mineral substances (N'guessan et al., 2009). Pourchez (2011) has also shown that they have long played a leading role in the monitoring and protection of fertility, childbirth and the early part of the life cycle of newborns.

In Africa, several studies have indicated that medicinal plants are used by rural populations to facilitate childbirth (Binimbi-Massengo et al., 2007; Folliard, 2008; N'guessan et al., 2010). In Côte d'Ivoire, despite ethnobotanical surveys carried out on medicinal plants (Kamanzi, 2002; Djah \& Malan, 2011; Béné et al., 2016), it should be noted that very few studies concerning this aspect of health by plants are available. The need to catalog this knowledge in order to safeguard it is therefore necessary. It is within this framework that this present work was carried out on medicinal plants traditionally used to facilitate childbirth in the
Department of Dabakala (Ivory Coast). The general objective is to contribute to improving knowledge of plants used by traditional birth attendants to facilitate childbirth with a view to their valuation. Specifically, it involves identifying and documenting information on medicinal plants as well as medicinal recipes used and offered by traditional birth attendants or midwives to facilitate childbirth in the department of Dabakala, located in the Sudanese savannah area.

\section{Material and methods Study site}

The study environment is the department of Dabakala in the Sudanese savannah zone, in the Center-North of Côte d'Ivoire (Figure 1). The town of Dabakala is located between $08^{\circ} 23$ ' $\mathrm{N}$ latitude and $04^{\circ} 26^{\prime}$ W longitude, with $258 \mathrm{~m}$ of altitude. The area straddles the Baoulean climate (in the South) and the Sudanese climate (in the North), with a predominance of the Sudanese climate. The latter is characterized by the dry and dusty wind of the Harmattan. The study area covers a total area of $9,671 \mathrm{~km} 2$ and has a density of 20 inhabitants per $\mathrm{km} 2$. It is bounded to the north by the department of Ferkessédougou, to the east by the departments of Bouna and Bondoukou and to the west by those of Katiola and Niakara (Ouattara, 2007).

\section{Data gathering \\ Sampling}

The present study was carried out from a series of ethnobotanical surveys using a pre-designed questionnaire (Zerbo et al., 2007; Tra Bi et al., 2008; Fah et al., 2013). The Department of Dabakala is made up of more than 100 villages. The choice of villages was made following a preliminary survey during an exploratory mission to the study area. Thus, the villages were selected on the one hand along transects going from the capital of the department and oriented in the four cardinal directions (North, South, East and West) along 4 road axes. On the other hand, we carried out a nonprobability sampling called oriented selection as a sampling method. The villages were selected for this purpose, based on their accessibility, the reputation of traditional birth attendants or traditional birth attendants in order to obtain information fairly representative of the study area. Thus, by the combination of these two methods, we selected 60 localities in the department of Dabakala (Figure 1).

\section{Traditional birth attendants met}

A total of 71 traditional birth attendants were interviewed. To achieve this, we followed local practices. Indeed, before the interview, a bottle of alcoholic drink or a sum of money in return for the service rendered was offered to our interlocutor. After the interview and before moving on to sample collection, a sum equivalent to the local price of a 
black chicken or often an alcoholic drink was also offered. This gesture symbolizing the authorization or the right to enter the forest or the savannah is compulsory. The questions were asked in the local language called Djimini. We benefited from the services of guide-interpreters.

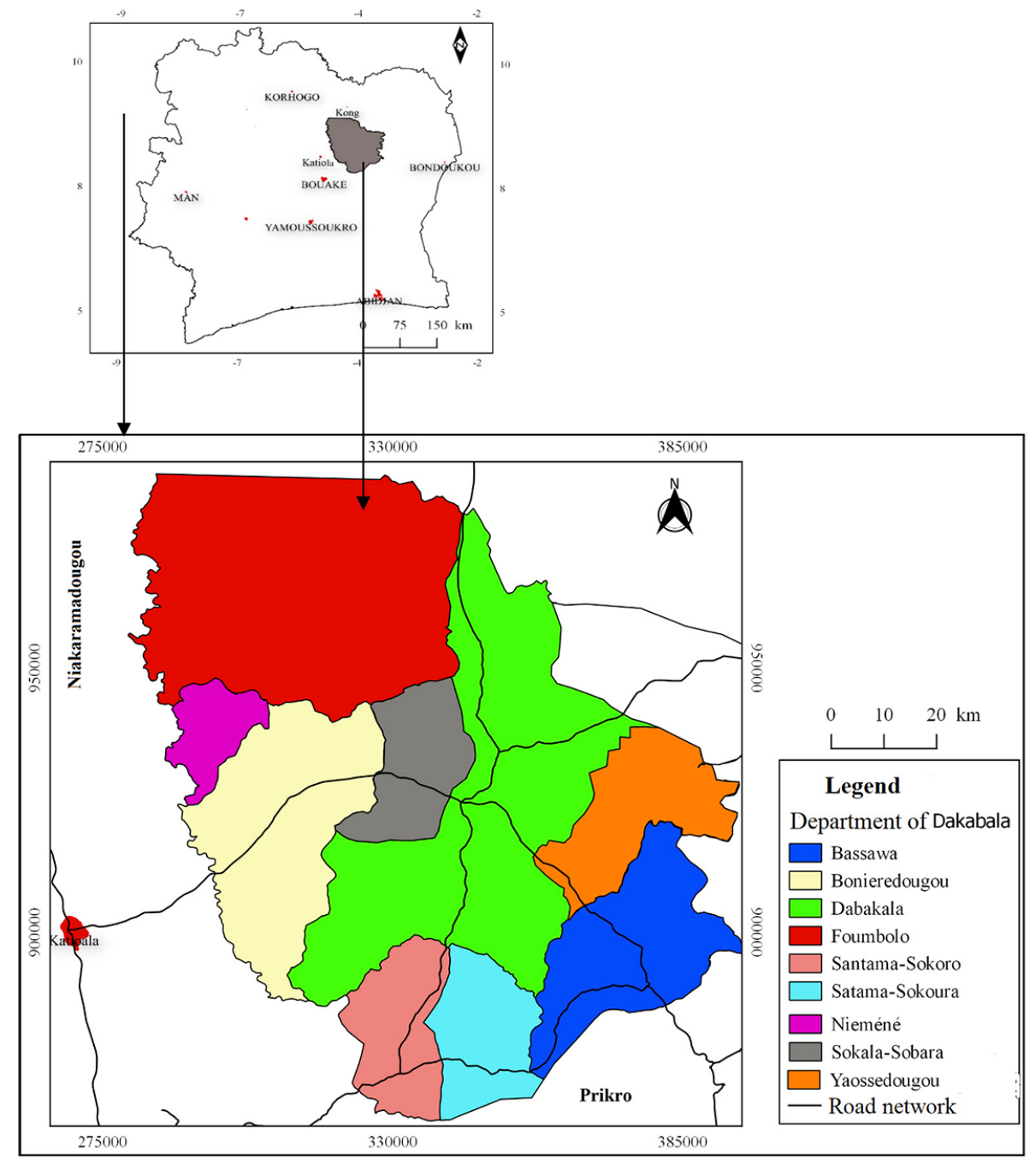

Figure 1. Sub-prefectures sampled and visited in the department of Dabakala

\section{Data processing}

The data were recorded on an Excel spreadsheet, then analyzed with Excel 2010, Epidata and SPSS 20.0 software. The Chi-square test (equality of distributions) was used to compare the percentages of the parts used, the method of preparation and the method of administration and allowed to check whether the differences are significant. To better interpret the medicinal cultural value of plants, several parameters have been determined. First, we assessed the consensus for the plant part used (CPP). Indeed, the CPP is the measure of the degree of agreement between informants concerning the part of the plant used:

$\mathrm{CPP}=\mathrm{Px} / \mathrm{Pt}$ (Byg \& Baslev, 2001; Monteiro et al., 2006).
Where $\mathrm{Px}=$ number of times a given plant part has been cited; $\mathrm{Pt}=$ total number of citations from all parties.

Then, it was a question of calculating the Frequency of the receipts ( $\mathrm{Fr}$ ) and the contribution of each plant in the constitution of the receipts (Cpr) (Byg \& Baslev, 2001; Monteiro et al., 2006; Dassou et al., 2014). Recipes with the highest $\mathrm{Fr}$ values are considered credible recipes. They are calculated by the following formulae:

$$
\mathrm{Cpr}=\mathrm{Nr} / \mathrm{Nt} \times 100
$$

Where $\mathrm{Nr}$ the number of recipes requesting the plant and $\mathrm{Nt}$ the total number of recipes and;

$$
\mathrm{Fr}=\mathrm{NCr} / \mathrm{N} \times 100
$$


Where Ncr is the number of citations of a recipe treating a given disease and $\mathrm{N}$ the number of total citations of all recipes treating the disease.

Finally, we finished by calculating the Relative Citation Frequency (FRC) and the Consensual Value of Use Types (Cs). For the present study, we used the original formula given by Dossou et al., (2012). Thus, this frequency is calculated as follows:

$$
\mathrm{FRC}=\mathrm{S} / \mathrm{N} \times 100
$$

Where $S$ is the number of people who provided an answer in relation to a given use and $\mathrm{N}$ is the total number of people interviewed.

For the second index, which measures the degree of agreement between the people interviewed in relation to the uses of the species (Thomas et al., 2009; Monteiro et al., 2006), it is expressed by :

$$
\mathrm{Cs}=2 \mathrm{ni} / \mathrm{n}-1
$$

Where $\mathrm{ni}$ is the number of people using a species in a given use category and $\mathrm{n}$ is the total number of interviewees. It is between [-1 and 1]. If $\mathrm{ni}=0$; $\mathrm{Cs}=$ -1 and if $n i=n ; C s=1$. This reflects the degree of consensus of the respondents on a particular use.

\section{Results}

\section{Richness and floristic composition}

In total, we identified 48 medicinal plants (Table 1) divided between 41 genera and 28 families. These species are involved in the preparation of 64 medicinal recipes, 14 of which are associations of 2 plants. The plants listed are composed of 17 trees, 8 shrubs, 5 shrubs, 17 grasses and 1 liana (Table 2).

Table 1. Number of genera and species per family used to facilitate childbirth

\begin{tabular}{lcc}
\hline Families & Species & Genera \\
\hline Fabaceae & 7 & 5 \\
\hline Annonaceae & 3 & 3 \\
\hline Asteraceae & 3 & 2 \\
\hline Combretaceae & 3 & 2 \\
\hline Euphorbiaceae & 3 & 2 \\
\hline Malvaceae & 3 & 3 \\
\hline Meliaceae & 2 & 2 \\
\hline Moraceae & 2 & 1 \\
\hline Rutaceae & 2 & 2 \\
\hline${ }^{*}$ Other & 1 & 1 \\
\hline${ }^{*}$ Zingiberaceae, Amaranthaceae, Apocynaceae, Bignoniaceae, Boraginaceae, Cannabaceae, \\
Chrysobalanaceae, Cyperaceae, Lamiaceae, Myrtaceae, Papaveraceae, Phyllanthaceae, Piperaceae, \\
Plantaginaceae, Poaceae, Portulacaceae, Sapindaceae, Sapotaceae, Solanaceae \\
\hline
\end{tabular}

Table 2. Distribution of the different biological forms of plants used to facilitate childbirth

\begin{tabular}{lcccc}
\hline & \multicolumn{2}{c}{ Number of species } & \multicolumn{2}{c}{ Number of citations } \\
\hline Morphological types & Djimini & Djamala & Djimini & Djamala \\
\hline Tree & 17 & 4 & 45 & 40 \\
\hline Shrub & 5 & 1 & 21 & 25 \\
\hline Bush & 8 & 2 & 26 & 30 \\
\hline Weed & 17 & 7 & 75 & 80 \\
\hline Liana & 1 & 1 & 9 & 10 \\
\hline
\end{tabular}

Diversity of knowledge and categorization of uses of plant organs

The ethnobotanical survey interviewed 71 traditional birth attendants in Dabakala department. Almost all of the traditional birth attendants met are animists (92\%) and belong to the Djimini ethnic group (75\%). Most of them have more than twenty years of experience $(47.9 \%)$.
Regarding the level of education of traditional birth attendants in Dabakala department, the results show that $74.6 \%$ are out of school. Adults ranging in age from 55 to 65 are the age group most involved in this activity, with $73.2 \%$ of respondents (Table 3 ). 
Table 3. Sociodemographic characteristics of traditional birth attendants in the department of Dabakala $(n=71)$.

\begin{tabular}{ccc}
\hline Settings & Effective & Percentage \\
\hline Ethnic group & & \\
\hline Djamala & 18 & 25 \\
\hline Djimini & 53 & 75 \\
\hline Years of experience & & \\
\hline $\mathbf{1 0}$ & 7 & 9,9 \\
\hline $\mathbf{1 5}$ & 9 & 12,7 \\
\hline $\mathbf{2 0}$ & 34 & 47,9 \\
\hline $\mathbf{2 5}$ & 11 & 15,5 \\
\hline $\mathbf{3 0}$ & 10 & 14,1 \\
\hline Educational level & & \\
\hline illiterate & 18 & 25,4 \\
\hline literate & 53 & 74,6 \\
\hline Age class & & \\
\hline $\mathbf{5} 5 \mathbf{5}$ & 11 & 15,5 \\
\hline ] 55-65] & 52 & 73,2 \\
\hline ] $65 ;+[$ & 8 & 11,3 \\
\hline
\end{tabular}

Regarding the parts of plants used, six types of organs are used to facilitate childbirth (Table 4). In addition to these different organs, the whole plant of certain herbs is also used. The leaves (55\%), the bark of the stems (19\%) and the whole plant (12\%) are the most used organs, taking into account their consensus for the plant part.

Table 4. Proportions of plant organs to facilitate childbirth

\begin{tabular}{lll}
\hline Part used & Effective & $\begin{array}{l}\text { Consensus for the } \\
\text { plant part (CPP) }\end{array}$ \\
\hline Leaves & 251 & 55 \\
\hline Stem bark & 87 & 19 \\
\hline $\begin{array}{l}\text { Whole } \\
\text { plant }\end{array}$ & 55 & 12 \\
Fruits & 37 & 8 \\
\hline Root bark & 18 & 4 \\
\hline Seed & 4 & 1 \\
\hline Rhizome & 3 & 1 \\
\hline Chi-square $\mathbf{= 9 4 9 , 9 5 ;} \mathbf{p}<\mathbf{0 , 0 0 1 ; ~} \mathbf{d l}=\mathbf{6}$ \\
\hline
\end{tabular}

Thus, to facilitate the administration of drugs, eight preparation techniques are employed namely: decoction, kneading, maceration, calcination, chewing, trituration, infusion and expression. Among them, decocté is the most widely used medicinal form (Figure 3).

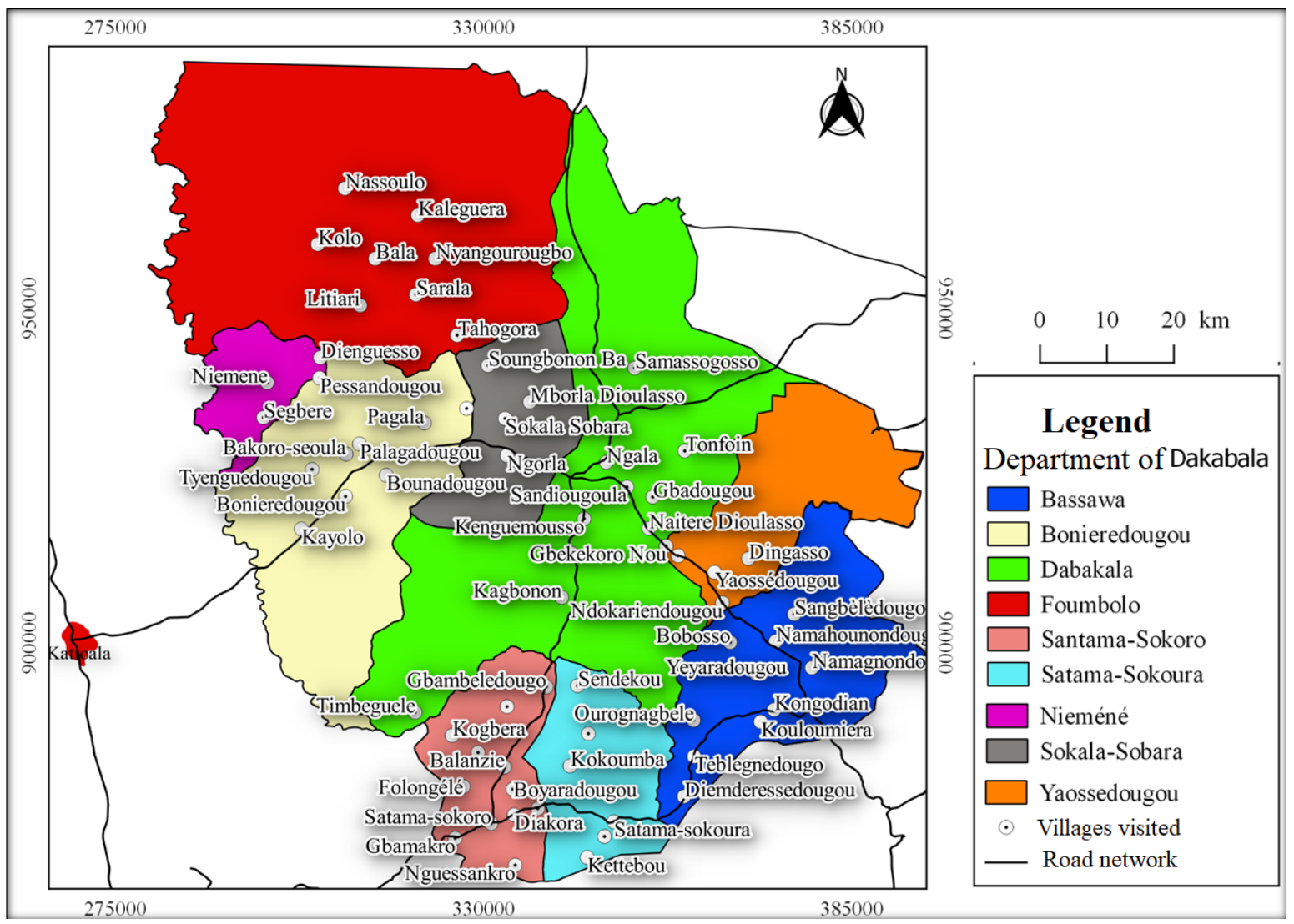

Figure 2.The localities sampled and visited in the department of Dabakala 
The different routes of administration (Figure 4) used to facilitate childbirth in the Dabakala department are the oral route $(53 \%)$, the cutaneous route $(35 \%)$ and the anal route $(12 \%)$.

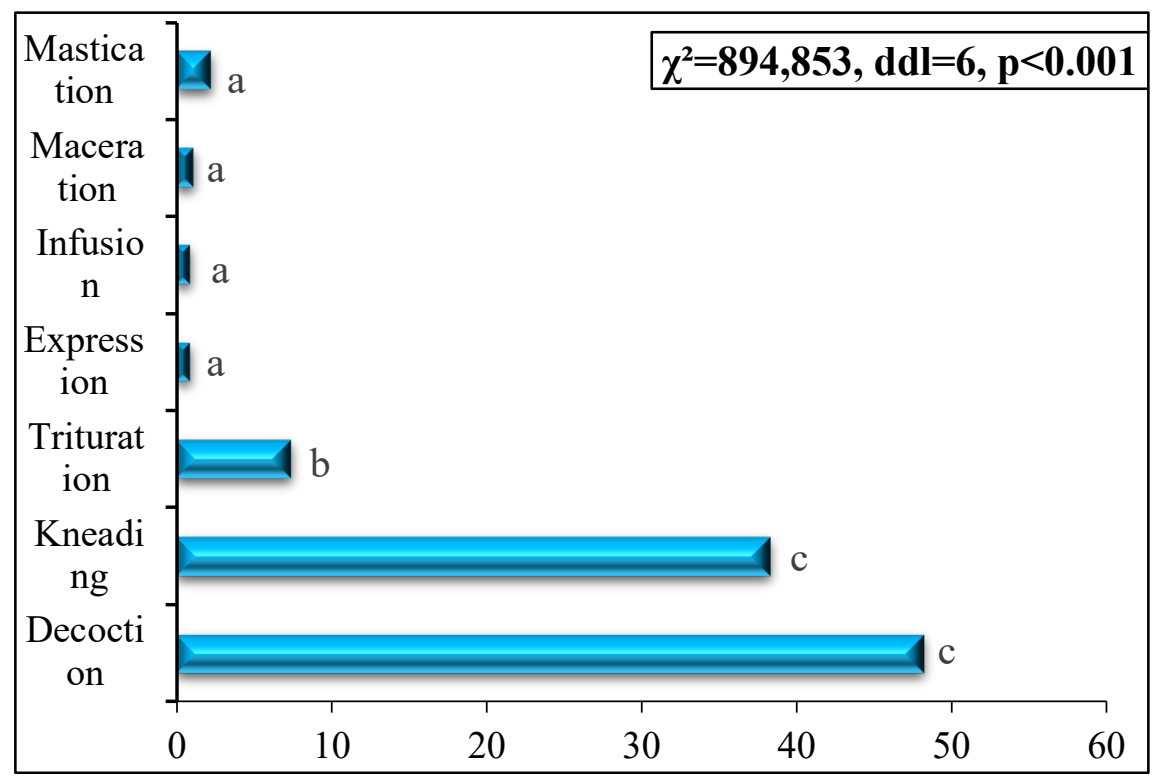

Figure 3. Distribution of techniques for preparing drug recipes to facilitate childbirth (for each technique used, the bars with the same letters are statistically identical)

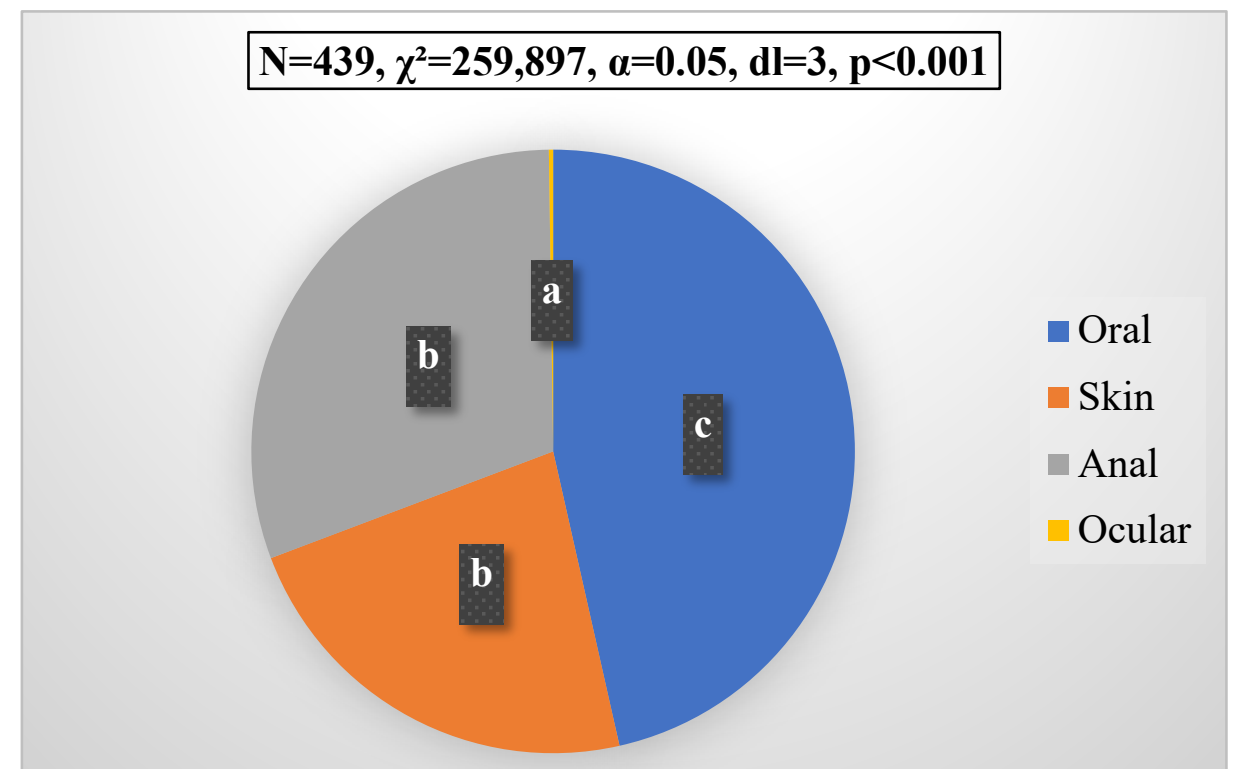

Figure 4. Distribution of modes of administration for children's health (for each mode used, bands with the same letters are statistically identical).

\section{Socio-cultural value of the plants listed}

The values of the different indices put species such as Portulaca oleracea, Alternanthera pungens, Ocimum americanum, Uvaria tortilis, Blighia sapida, Trema guineensis in the first position (Table 5). Indeed, the results obtained showed that Citrus limon contributed the most in the constitution of the recipes to facilitate childbirth with a high $\mathrm{CPr}(6.25)$. Next to this, certain species come in the background. These are Trema guineensis, Capsicum frutescens, Combretum glutinosum, Cassia occidentalis, Heliotropium indicum, Combretum micranthum, Desmodium adscendens, Scoparia dulcis, Xylopia aethiopica, Arachis hypogaea, Solanum distichum and Zingiber officinale (Table 5). The most requested recipes come from species such as Portulaca oleracea, Alternanthera pungens, Ocimum americanum, Uvaria tortilis, Blighia sapida, Trema guineensis given their high Frequency of recipes (Fr) (Table 5). In short, the species most requested by traditional birth attendants to facilitate childbirth by taking into account the relative frequencies of citation and the degree of consensus of the respondents are Portulaca oleracea, Alternanthera pungens, Ocimum americanum, Uvaria tortilis, Blighia sapida and Trema guineensis (Table 5). 
Table 5. List of plants used to facilitate childbirth and their cultural significance.

\begin{tabular}{|c|c|c|c|c|c|c|c|c|}
\hline Scientific names & Families & $\begin{array}{l}\text { Vernacular I } \\
\text { common names }\end{array}$ & $\mathrm{NCr}$ & FCR & $\mathrm{Nr}$ & $\mathrm{CPr}$ & $\mathrm{Fr}$ & Cs \\
\hline Portulaca oleracea L. & Portulacaceae & Nandini & 51 & 71,83 & 1 & 1,56 & 13,67 & 0,44 \\
\hline Alternanthera pungens Kunth & Amaranthaceae & Kambessaba & 32 & 45,07 & 1 & 1,56 & 8,58 & $-0,10$ \\
\hline Ocimum americanum $\mathrm{L}$ & Lamiaceae & Pounafini & 27 & 38,03 & 1 & 1,56 & 7,24 & $-0,24$ \\
\hline Uvaria tortilis A. Chev. ex Hutch. \& Dalziel & Annonaceae & Pedjan & 20 & 28,17 & 1 & 1,56 & 5,36 & $-0,44$ \\
\hline Blighia sapida K. D. Koenig & Sapindaceae & Gôkougô & 18 & 25,35 & 1 & 1,56 & 4,83 & $-0,49$ \\
\hline Trema orientalis (L.) Blume & Cannabaceae & Mougon & 17 & 23,94 & 2 & 3,13 & 4,56 & $-0,52$ \\
\hline Argemone mexicana L. & Papaveraceae & Drassifi & 15 & 21,13 & 1 & 1,56 & 4,02 & $-0,58$ \\
\hline Capsicum annuum L. & Solanaceae & Gbéhé & 15 & 21,13 & 2 & 3,13 & 4,02 & $-0,58$ \\
\hline Piliostigma thonningii (Schum.) Millne-Redhead & Fabaceae & Yewagnan & 13 & 18,31 & 1 & 1,56 & 3,49 & $-0,63$ \\
\hline Phyllanthus amarus Schum. \& Thonn. & Phyllanthaceae & $\begin{array}{l}\text { Sougnassi } \\
\text { (Malinké) }\end{array}$ & 12 & 16,90 & 1 & 1,56 & 3,22 & $-0,66$ \\
\hline Combretum glutinosum Perr. ex DC. & Combretaceae & Wobihin & 9 & 12,68 & 2 & 3,13 & 2,41 & $-0,75$ \\
\hline Citrus limon Burn. $\mathrm{f}$. & Rutaceae & Lomourougban & 9 & 12,68 & 4 & 6,25 & 2,41 & $-0,75$ \\
\hline Senna occidentalis (L.) Link. & Fabaceae & Gbangbonon & 9 & 12,68 & 2 & 3,13 & 2,41 & $-0,75$ \\
\hline Jatropha gossypiifolila L. & Euphorbiaceae & Kapara & 8 & 11,27 & 1 & 1,56 & 2,14 & $-0,77$ \\
\hline Kigelia africana (Lam.) Benth. & Bignoniaceae & Sidjan & 8 & 11,27 & 1 & 1,56 & 2,14 & $-0,77$ \\
\hline Parkia biglobosa (Jacq.) Benth. & Fabaceae & Nindigué & 8 & 11,27 & 1 & 1,56 & 2,14 & $-0,77$ \\
\hline Annona senegalensis Pers. & Annonaceae & Lofigué & 7 & 9,86 & 1 & 1,56 & 1,88 & $-0,80$ \\
\hline Heliotropium indicum L. & Boraginaceae & Tchegorlornifoulé & 7 & 9,86 & 2 & 3,13 & 1,88 & $-0,80$ \\
\hline Aspilia bussei O. Hoffm. \& Muschler & Asteraceae & Deniwor & 6 & 8,45 & 1 & 1,56 & 1,61 & $-0,83$ \\
\hline Euphorbia hirta L. & Euphorbiaceae & Djêwirimin & 6 & 8,45 & 1 & 1,56 & 1,61 & $-0,83$ \\
\hline Ficus sur Forsk. & Moraceae & Ndassaga & 6 & 8,45 & 1 & 1,56 & 1,61 & $-0,83$ \\
\hline Vitellaria paradoxa C.F. Gaertn. & Sapotaceae & Létigué & 6 & 8,45 & 1 & 1,56 & 1,61 & $-0,83$ \\
\hline Maranthes robusta (Oliv.) Prance & Chrysobalanaceae & Kôbro & 6 & 8,45 & 2 & 3,13 & 1,61 & $-0,83$ \\
\hline Cola nitida (Vent.) Schott \& Endl. & Malvaceae & Gbêyê & 5 & 7,04 & 1 & 1,56 & 1,34 & $-0,86$ \\
\hline Azadirachta indica A. Juss. & Meliaceae & $\begin{array}{l}\text { Djokouadjo-brou } \\
\text { (Malinké) }\end{array}$ & 4 & 5,63 & 1 & 1,56 & 1,07 & $-0,89$ \\
\hline Zanthoxylum Zanthoxyloides (Lam.) Zepern. \& Timler & Rutaceae & Nganhan & 4 & 5,63 & 1 & 1,56 & 1,07 & $-0,89$ \\
\hline Ageratum conyzoides $\mathrm{L}$. & Asteraceae & $\begin{array}{l}\text { Moussocôrôni- } \\
\text { cougê (Malinké) }\end{array}$ & 3 & 4,23 & 1 & 1,56 & 0,80 & $-0,92$ \\
\hline Anogeissus leiocarpus (DC.) Guill. \& Perr. & Combretaceae & Nglaga & 3 & 4,23 & 1 & 1,56 & 0,80 & $-0,92$ \\
\hline Combretum micranthum G. Don & Combretaceae & $\begin{array}{l}\text { N'golobè } \\
\text { (Malinké) }\end{array}$ & 3 & 4,23 & 2 & 3,13 & 0,80 & $-0,92$ \\
\hline Psidium guajava L. & Myrtaceae & Tagnirimin & 3 & 4,23 & 1 & 1,56 & 0,80 & $-0,92$ \\
\hline Scoparia dulcis L. & Plantaginaceae & Gaigniwoué & 3 & 4,23 & 2 & 3,13 & 0,80 & $-0,92$ \\
\hline
\end{tabular}




\begin{tabular}{|c|c|c|c|c|c|c|c|c|}
\hline Xylopia aethiopica (Dunal) A. Rich. & Annonaceae & Kanifi(Malinké) & 3 & 4,23 & 2 & 3,13 & 0,80 & $-0,92$ \\
\hline Adansonia digitata $\mathrm{L}$. & Malvaceae & Sira (Malinké) & 2 & 2,82 & 1 & 1,56 & 0,54 & $-0,94$ \\
\hline Arachis hypogaea L. & Fabaceae & Kougbô & 2 & 2,82 & 2 & 3,13 & 0,54 & $-0,94$ \\
\hline Aspilia africana (Pers.) Adams ssp. africana & Asteraceae & $\begin{array}{l}\text { Soumadibrou } \\
\text { (Malinké) }\end{array}$ & 2 & 2,82 & 1 & 1,56 & 0,54 & $-0,94$ \\
\hline Carapa procera (DC.) De Wilde & Meliaceae & Krougbêguê & 2 & 2,82 & 1 & 1,56 & 0,54 & $-0,94$ \\
\hline Senna alata (L.) Roxb. & Fabaceae & Kadja & 2 & 2,82 & 1 & 1,56 & 0,54 & $-0,94$ \\
\hline Senna hirsuta (L.) H.S. Irwin \& Barneby & Fabaceae & $\begin{array}{l}\text { Kinkeliba- } \\
\text { moussoman } \\
\text { (Malinké) }\end{array}$ & 2 & 2,82 & 1 & 1,56 & 0,54 & $-0,94$ \\
\hline Desmodium adscendens (Sw.) DC. & Fabaceae & $\begin{array}{l}\text { Tika-brou } \\
\text { (Malinké) }\end{array}$ & 2 & 2,82 & 2 & 3,13 & 0,54 & $-0,94$ \\
\hline Ficus exasperata Vahl & Moraceae & Yewoulê & 2 & 2,82 & 1 & 1,56 & 0,54 & $-0,94$ \\
\hline Jatropha curcas Linn. & Euphorbiaceae & Kapara & 2 & 2,82 & 1 & 1,56 & 0,54 & $-0,94$ \\
\hline Piper guineense Schum. \& Thonn. & Piperaceae & Fêfê (Malinké) & 2 & 2,82 & 1 & 1,56 & 0,54 & $-0,94$ \\
\hline Solanum distichum Schumach. \& Thonn. & Solanaceae & Gnangnan & 2 & 2,82 & 2 & 3,13 & 0,54 & $-0,94$ \\
\hline Zingiber officinale Rosc. & Zingiberaceae & Tragbéhé & 2 & 2,82 & 2 & 3,13 & 0,54 & $-0,94$ \\
\hline Bombax costatum Pellegr. \& Vuillet & Malvaceae & $\begin{array}{l}\text { Boumboum } \\
\text { (Malinké) }\end{array}$ & 1 & 1,41 & 1 & 1,56 & 0,27 & $-0,97$ \\
\hline Calotropis procera (Ait.) Ait. f. & Apocynaceae & $\begin{array}{l}\text { Vogo Vogo } \\
\text { (Baoulé) }\end{array}$ & 1 & 1,41 & 1 & 1,56 & 0,27 & $-0,97$ \\
\hline Cymbopogon citratus (DC.) Stapf & Poaceae & $\begin{array}{l}\text { Amagnésin } \\
\text { (Baoulé) }\end{array}$ & 1 & 1,41 & 1 & 1,56 & 0,27 & $-0,97$ \\
\hline Cyperus esculentus L. & Cyperaceae & $\begin{array}{l}\text { Tchongon } \\
\text { (Malinké) }\end{array}$ & 1 & 1,41 & 1 & 1,56 & 0,27 & $-0,97$ \\
\hline
\end{tabular}


These species may be of interest in the treatment of conditions related to female infertility. Also, the comparison of the general list of species with that of the IUCN (2015) and that of Aké-Assi (1998) allowed us to identify 4 plant species with special status.

These are 2 species on the IUCN Red List and 2 species on the Aké-Assi list of special status species. Regarding the IUCN, we have 1 species of Least Concern (L.C), Desmodium adscendens and one vulnerable species (VU) including Vitellaria paradoxa. Regarding species with special status according to Aké-Assi, we note the presence of 2 rare species, which have become rare and endangered. These are Uvaria tortilis and Maranthes robusta.

\section{Discussion}

The results of our survey show that the traditional use of medicinal plants during pregnancy is still an existing practice in our societies. During our investigation, we identified 48 medicinal plants used to facilitate childbirth in the department of Dabakala. Our results are lower on the one hand than those of Malan and Neuba (2011). Indeed, these authors have identified 75 medicinal plants used during pregnancy by the women of Anyi-Ndenye (East, Ivory Coast). On the other hand, these results are superior to those of N'guessan et al. (2010) who in their studies inventoried 34 species of plants to facilitate childbirth among the Abbey and Krobou, in the south of the Ivory Coast. The comparison of our results with these different works shows that the inventories have the same characteristics in all the studies. In fact, spermaphytes constitute the main part of the arsenal of plants with an oxytocic effect. Also, the comparison of the results reveals that they have in common $30 \%$ of the species used to facilitate childbirth. We note in Ouattara (2006), 03 plants representing $1.78 \%$ of the repertoire of plants identified during the ethnopharmacological study carried out in Dida country, in the region of Divo (southern Ivory Coast). This representativeness was not observed during ethnobotanical surveys carried out in the department of Transua in the District of Zanzan (Béné et al., 2016). In his study, the author shows that 08 plant species $(7 \%)$ constitute the bulk of the arsenal of taxa used to facilitate childbirth. However, there is variability in the number of individuals counted from one study to another. This variability is thought to be due to variations in the methods of investigation. In addition, it could also be explained by the differences in localities and vegetation varying from one phytogeographic zone or district to another within the country (Adomou, 2011).

We note that some plants listed in this study have been referred to by other authors for their oxytocic effect. Indeed, it is Cola nitida and Portulaca oleracea used in Ivory Coast to ensure the proper development of pregnancy (Béné et al., 2016). It turned out in this study that some inventoried species are vulnerable or rare species. The fact that certain species have a vulnerability status can be justified by the strong anthropogenic pressure due to wide use by populations in rural areas in most of the localities where they are present. The vast majority of these vulnerable plants are used for both food and pharmacopeia in Africa (Muok et al., 2011). This is the case with Vitellaria paradoxa, very common in the study area. It is a plant that is protected and managed by traditional conservation methods because of its useful role and / or its economic importance for the populations (Koné, 2005). According to Soro (2008), this woody species is strongly integrated into traditional farming systems. It is ubiquitous throughout the savannah region.

Healing involves, in addition to treatments by plants, animals and minerals, rites and incantations. To achieve this, various parts are taken from the plant to prepare the drug recipes. Concerning the frequency used per organ, the leaves are more cited. For the preparation method, the decoction that is more practiced. These results are consistent with previous studies (Dongock et al. 2017). The leaves are mostly used, followed by the use of stem bark, root bark and fruit (Nsonde Ntandou et al., 2005).

The Interest in leaves and barks is explained by the fact that they are the par excellence location of biosynthesis and even the storage of secondary metabolites responsible for the plant's biological properties (Mangambu et al., 2014). For this author, these organs constitute the storage places of secondary metabolites or chemical groups, protective of the organism. The easy access and regeneration of these leaves could also justify their important use. It is also known that the use of bark and roots severely compromise the survival of the species sought (Houmenou et al., 2017). This may also be a reason for the preferential use of leaves. In addition, if the removal of $50 \%$ of the leaves does not lead to the disappearance of the plant, the same is not true for the root or bark (Ouattara, 2006). For this purpose, Poffenberger (1992) indicates that circular peeling would eventually end by killing the plant.

The decoction can last a few seconds to a few minutes, or even a few hours depending on the substance, the principles to be extracted or the desired taste. It also allows the sterilization of the herbal tea. On the other hand, maceration is the longest extraction method, it consists in letting the plant sample (s) macerate in a liquid (water, oil, alcohol, vinegar, etc.) in order to extract the active ingredients. It usually lasts several hours or even 
weeks and the extract may not be sterilized (Camara, 2011). It is perhaps for these reasons that the decoction is more practiced than the other forms of preparation.

The Fabaceae family is the one with the largest number of plants, used by the traditional birth attendants interviewed. Indeed, this large family is one of the richest families in medicinal plants of the Ivorian flora (Aké-Assi, 2001; N'Guessan et al., 2010). The results obtained are consistent with recent studies carried out in Côte d'Ivoire by Orsot (2016) and Béné et al. (2016). Also, the Asteraceae and Euphorbiaceae families represent a large number of representative families to facilitate childbirth. This representativeness was observed during ethnobotanical surveys carried out by Malan and Neuba (2011) in the locality of Yakassé-feyassé (Eastern Côte d'Ivoire).

As regards the morphological types, the most numerous are the herbaceous and woody plants. The latter thus attest to the strong use of woody plants in the traditional pharmacopeia of the CenterNorth of Côte d'Ivoire (Diatta et al., 2013). Also, the predominance of herbs is linked to the period of availability and harvest. Indeed, the species most used by populations are those which develop in their immediate environment and which are easily accessible (Lamien et al., 2004). Also, the presence of mostly herbaceous plants can be explained by their proximity and abundance around homes or near villages (Mangambu et al., 2014). The same is true for Mangambu et al. (2008) who found that there are $52 \%$ herbaceous plants and $48 \%$ trees in a study of Congolese flora. Adamou et al. (2012) find opposite results in an ethnobotanical study of medicinal plants sold in the Abomey-Calavi market in Benin, where trees are more represented.

Notwithstanding the secret nature of their function, the reciprocity of uses of the plants used by traditional birth attendants, would demonstrate that the latter also manage to exchange knowledge among themselves. These claims are supported by the high rate of the relative citation frequency index ( $>20 \%$ ) and use value at the predominant species level. Thus, these different high values could mean not only that these plants are more available and better known by traditional birth attendants. These herbs may be the most effective in facilitating childbirth. More than half of the species listed (52\%) are each mentioned by only one interviewee (FRC = $1.41 \%)$. This result could mean that the holders of endogenous knowledge still keep to themselves a good part of their knowledge despite the existence of the network of traditional healers led by the National Program for the Promotion of Traditional Medicine (PNPMT) in Côte d'Ivoire. Also, these high index values of the predominant species would constitute evidence of their continued use for a specific disease, of collective knowledge on the use of these plants and potentially, of an exchange of information between birth attendants of the study area. These exchanges do not only take place between members of the same community there were cases where a Djimini midwife transmits a secret to another of the Djamala ethnic group and vice versa. Belonging to the same religion can also build a bridge of trust between two communities in the transfer of knowledge. These results are therefore similar to those of Goussanou et al. (2011) who instead focus on cultural mixing and inter-village relations as factors favoring the transfer of knowledge within populations. You might also think that they also sell their knowledge when necessary. However, this situation testifies to the complexity of the field of medicine and traditional pharmacopeia (Zerbo, 2007). Indeed, the recipes and the knowledge of the plants that go into their composition constitute secrets that are only entrusted to a third party when the custodian wishes (llumbe, 2010).

\section{Conclusion}

Surveys carried out with traditional birth attendants in the various localities of the Dabakala department have identified 48 medicinal recipes. They are made from 64 different species of medicinal plants and used, often on their own, but mostly in combination with other plant species. Portulaca oleracea, Alternanthera pungens, Ocimum americanum, Uvaria tortilis, Blighia sapida are the plants most in demand for their oxytocic effect in the department of Dabakala. These different plants and recipes have specific actions and are best suited for the treatment of a particular form of cause and effect oxytoxicity. According to our bibliography, several of the plants listed have not yet been the subject of laboratory studies to verify their oxytocic effect. They could therefore constitute interesting research subjects. However, phytochemical screening in the laboratory is necessary to know the chemical compounds contained in the main plants used and their degree of toxicity.

\section{Declarations}

Abreviations: AIBEF: the Ivorian Association for Family Welfare; APG III: Phylogenetic Group of Angiosperms III; CHWs: Community health workers; CASES: Center for Health and Social Studies; CPP: Consensus for the Plant Part; Cpr: Contribution of each plant in the constitution of recipes; Cs: Consensus value of types of use; Fr: Frequency of receipts; FRC: Relative citation frequency; LC: Species of Least Concern according to IUCN; NR: number of recipes; NC: number of citations; NGO: Non-governmental organization; SPSS: Stastistical 
Package for Social Science; IUCN: International Union for Conservation of Nature; VU: Vulnerable species according to IUCN

Ethicas approval and consent to participate: Prior to conducting the interviews, prior informed consent was obtained from all participants. No other approved ethics were required.

Consent to publication: Not applicable

Availability of data and materials: the data has not been deposited in public repositories.

Competing interests: The authors have no competing interests.

Funding: This study was funded by the NGO CASES (Center for Health and Social Studies) for the collection of data in the field.

Author Contributions: The authors were actively engaged in writing the study proposals and design, field data collection, data analysis, and manuscript writing.

\section{Acknowledgments}

Our thanks go to the village chiefs, community counselors, community health workers ( $\mathrm{CHWs}$ ) as well as traditional birth attendants for their accessibility, availability and frank collaboration in this study. We also thank the NGO CASES (Center for Health and Social Studies) which was in favor of carrying out this study. Finally, we would like to thank Mr. late ASSI Yapo Jean, Botanist technician at the National Floristic Center, Félix HOUPHOUETBOIGNY University for his contribution to the identification of the plants listed.

\section{Literature cited}

Adomou AC, Agbani OP, Sinsin B. 2011. Plants. In Protection of Nature in West Africa: A Red List for Benin. Nature conservation in West Africa: Red List of Benin, Neuenschwander P, Sinsin B, Goergen G (eds). International Institute of Tropical Agriculture: Ibadan, Nigeria Pp. 21-46.

Aké Assi L. 2001. Flora of Côte d'Ivoire: systematic catalog, biogeography and ecology. Geneva. Boissiera 57, 1- 396.

Aké-Assi L. 1998. Impact of logging and agricultural development on the conservation of biological diversity in Côte d'Ivoire. The flaming 48: 20-22.

APG III, 2009. An update of the Angiosperm Phylogeny Group classification for the orders and families of flowering plants: APG III. Botanical Journal of the Linnean Society 161: 105-121.

Béné K, Camara D, Fofié N'BY, Kanga Y, Yapi AB, Yapo YC, Ambe SA, Zihiri GN. 2016. Ethnobotanical study of medicinal plants used in the Department of Transua, District of Zanzan (Ivory Coast). Journal of Animal \& Plant Sciences 27 (2): 4230-4250.

Binimbi-Massengo A, N'Zongi J, Abena AA \& Diatewa M 2007. Inventory of medicinal plants used in the treatment of threatened abortion in Brazzaville.
African Medicinal Pharmacology Review 20: 155164.

Byg A, Baslev H. 2001. Diversity and use of palms in Zahamena, eastern Madagascar. Biodiversity and Conservation 10, 951-970.

Dassou GH, Ogni CA, Yédomonhan H, Adomou AC, Tossou M, Dougnon JT, Akoègninou A. 2014. Diversity, ethnobotany and vulnerability of plants for veterinary use in North Benin. International Journal of Biological and Chemical Sciences 8 (1): 189-210.

Dossou ME, Houessou GL, Lougbégnon OT, Tenté AHB, Codjia JTC. 2012. Ethnobotanical study of forest-wood resources of the Agonvè swamp forest and related terroirs in Benin. Tropicultura 30 (1): 4148.

Diatta CD, Gueye M, Akpo LE. 2013. Medicinal plants used against dermatoses in the Baïnounk pharmacopoeia of Djibonker, Senegal. Journal of Applied Biosciences 70: 5599-5607.

Djah, FM and Danho FN. 2011. Traditional Practices and Medicinal Plants Used During Pregnancy by Women in Anyi-Ndenye (Eastern Ivory Coast). African Journal of Reproductive Health 15 (1): 85-93.

Dongock Nguemo D, Mapongmetsem PM, Abdoulaye M, Noiha Noumi V. 2017. Ethnological studies on melliferous plants of the SoudanoSahelian Zone of Chad. Journal of Medicinal Plants Studies 5 (3): 193-198.

Fah L, Klotoé JR, Dougnon V, Koudokpon H, Fanou VBA, Dandjesso C. and Loko F. 2013. Ethnobotanical study of plants used in the treatment of diabetes in pregnant women in Cotonou and Abomey-Calavi (Benin). Journal of Animal \& Plant Sciences 18 (1): 2647-2658.

Folliard T. 2008. External herbal medicine in South and Central America Mexico and Guatemala. Journal of African Medicine and Pharmacy 20: 175183.

Houmenou V, Adjatin A, Tossou M G, Yedomonhan H, Dansi A, Gbenou J, Akoegninou. 2017. Ethnobotanical study of plants used in the treatment of female infertility in the departments of Ouémé and Plateau in South Benin. International Journal of Biological and Chemical Sciences 11 (4): 18511871.

llumbe G. 2010. Use of plants in traditional medicine by the Pygmies (Ba-twa) and Bantu (Ba-Oto) of the territory of Bikoro, Equateur province in DR Congo. Doctoral thesis at the Université Libre de Bruxelles (Belgium), $237 \mathrm{p}$.

Kamanzi A. 2002. Medicinal plants from Côte d'Ivoire. Phytochemical investigations guided by biological assays. State Doctorate Thesis, University of Cocody-Abidjan, U.F.R. Biosciences, Botanical Laboratory, $300 \mathrm{p}$. 
Koné WM. 2005. Potential of medicinal plants from Côte d'Ivoire in the control of haemonchoses in sheep. University of Cocody Abidjan UFR Biosciences Unique Doctoral Thesis in Plant Biology, Specialty: Phytochemistry: 224.

Lamien N, Coulibaly-Lingani P, Traoré S, Ouédraogo S, Parkouda C, Bognounou O. 2004. Wild fruit trees in Burkina Faso: Contribution to food security and biodiversity conservation. Provisional technical report for the period (April 2003-March 2004), Burkina Faso. Bobo-Dioulasso (Burkina Faso): CRDI.

Malan DF, Neuba DFR. 2011. Traditional Practices and Medicinal Plants Use during Pregnancy by AnyiNdenye Women (Eastern Côte d'Ivoire), African Journal of Reproductive Health 15 (1): 85-9.

Mangambu M, Kamabu V, Bola MF. 2008. Medicinal plants used in the treatment of asthma in Kisangani and its surroundings (Province Orientale, R. D. Congo). Annales des Sciences, Official University of Bukavu 1 (1) 63-68.

Mangambu M, Mushagalusa K, Kadima N. 2014. Contribution to the phytochemical study of some anti-diabetic medicinal plants in the city of Bukavu and its surroundings (Sud-Kivu, R.D.Congo). Journal of Applied Biosciences 75: 6211-6220.

Monterio JM, Albuquerque UP, Lins-Neto EMF, Araújo EL, Amorim ELC. 2006. Use patterns and knowledge of medicinal species among two rural communities in Brazil's semi-arid north eastern region. Journal of Ethnopharmacology 105: 173-186.

Muok BO, Khumalo SG, Tadesse W, Alem S. 2011. Sclerocarya birrea, African plum. Conservation and sustainable use of genetic resources of priority food woody species in sub-Saharan Africa. Biodiversity International (Rome, Italy). 12.

N'Guessan K, Kouassi K, Kouadio K. 2009. Ethnobotanical study of plants used in traditional medicine to treat diabetes, by Abbey and Krobou people of Agboville (Cote d'Ivoire). American Journal of scientific Research 4: 45-58.

WHO, 2019. Global Strategies for Women's, Children's and Adolescents' Health (2016-2030). Seventy-second World Health Assembly, 11p.

N'Guessan K, Zirihi NG, Boraud NTKM, 2010. Ethnopharmacological study of plants used to facilitate childbirth, in Abbey and Krobou country, in the south of the Ivory Coast. International Journal of Biological Chemical Sciences 4 (4): 1004-1016.

Ouattara D. 2006. Contribution to the inventory of significant medicinal plants used in the Divo region (southern forest of Côte d'Ivoire) and the diagnosis of the pepper tree of Guinea: Xylopia aethiopica (Dunal) A. Rich. (Annonaceae). Thesis, UFR Biosciences, University of Cocody, Abidjan, Ivory Coast, $156 \mathrm{p}$.
Ouattara KA. 2007. Technical and socio-economic analysis of a cashew nut plantation in Sokala Sobara, in the Department of Dabakala. Internship report at the end of the first agronomic year, ESA, INP-HB. 41p.

Orsot BAMB. 2016. Ethnobotanical study of medicinal plants used in the treatment of skin diseases by the Abbey of the Department of Agboville (Ivory Coast) and evaluation of the antifungal activity of extracts from four plants on Sclerotium rolfsii, a phytopathogen. Unique Doctorate Thesis in Botany, Félix Houphouët-Boigny University, Abidjan (Ivory Coast), 168p.

Poffenberger M., Gean B., Khare A. \& Campbell J., 1992. - Field method manual. In: Community forest economy and use patterns: Participatory Rural Apprasail (P.R.A.) methods in South Gujarat, India. Society for promotion of Wasteland development, Volume II, New Delhi (India), pp. 16-57.

Pourchez L. 2011. Women's knowledge: traditional medicine and nature - Mauritius, Réunion, Rodrigues. Local and indigenous knowledge, 1. UNESCO: Paris, $120 \mathrm{p}$.

Soro D. 2008. Fruit production and various derivatives of the Tengrela shea natural park (North of Côte d'Ivoire), in connection with pruning as a means of controlling Loranthaceae (parasitic vascular plants). Doctoral thesis, University of Cocody Abidjan, Botanical Laboratory, Plant Ecology Specialty: 141.

Thomas E, Vandebroek I, Sanca S \& Van Damme P. 2009. Cultural significance of medicinal plant families and species among Quechua farmers in Apillapampa, Bolivia. Journal of Ethnopharmacology 122: 60-67.

Tra Bi FH, IRIÉ G M, N'gaman KCC, Mohou CHB. 2008. Studies of some therapeutic plants used in the treatment of arterial hypertension and diabetes: two emerging diseases in Côte d'Ivoire. Sciences and Nature 5 (1): 39 - 48.

Yoro B M, Kané NS, Ehui PJ. 2017. Socioanthropological analysis of the collaboration between midwives / nurses and traditional birth attendants in the monitoring of pregnant women in rural areas Dan (Ivory Coast), European Journal of Social Science 54 (1): 103-112.

Zerbo P, Millogo-Rasodimby J, NacoulmaOuedraogo OG, Van Damme P. 2007. Contribution to the knowledge of medicinal plants used in childcare in San country, in Burkina Faso. International Journal of Biology Chemical Sciences 1 (3): 262-274. 